Лiтература:

1. Батьківське самоврядування в закладах освіти. URL: https://uhp.org.ua/wp-content/uploads/2016/11/fondy-03-10-new.pdf (дата звернення: 05.03.2021).

2. Поняття «консультативно-дорадчий орган» як категорія конституційного права. Нестерович В.Ф. URL: http://elar.naiau.kiev.ua/ bitstream/123456789/2848/1/ПОНЯТТЯ\%20»КОНСУЛЬТАТИВНОДОРАДЧИЙ\%20ОРГАН».pdf (дата звернення: 05.03.2021).

3. Про повну загальну середню освіту : Закон України від 01.08 .2020 p. 463-IX / Верховна Рада України. URL: https://zakon.rada.gov.ua/laws/show/463-20\#Text (дата звернення: 05.03.2021).

DOI https://doi.org/10.30525/978-9934-26-045-2-22

\title{
CARBON TAX MANAGEMENT IN THE EASTERN PARTNERSHIP COUNTRIES: MINIMIZING FINANCIAL RISKS OF EUROPEAN GREEN DEAL AND COVID-19 CRISIS
}

\author{
Moroz O. V. \\ Candidate of Physical and Mathematical Sciences, \\ Senior Research Fellow \\ Kyiv, Ukraine
}

The imperfection of the financial market determines the limitations of financial instruments for low-carbon investments [1, p. 19]. Constrained access to finance in many developing countries may limit their capacity to develop effective stimulus packages for the post-pandemic recovery [2, p. 6]. Actual tasks for approximation to international and EU mechanisms of functioning of the financial services system in Eastern Partnership $(E a P)$ countries and other developing still need to be solved by Governments, including the fulfillment of the Paris Agreement obligations [3].

Effective use of carbon taxes with another instruments could be a key solution to the problem of limited access to finance, exacerbated by the effects of Covid-19, and especially in the developing countries. That comes from unanimous independent conclusions of $\operatorname{OECD}[2$, p. 2, 6, 11], the World Bank [4, p. 4, 11], the International Monetary Fund [1, p. 8]; according to research of the Centre for Climate Change Economics and 
Policy \& the Grantham Research Institute on Climate Change and the Environment (UK) [5, p. 1], the Tax Policy Center/Urban Institute \& Brookings Institution (USA) [6], many other authoritative organizations and representatives of world scientific community.

Carbon taxes, as one of the mechanisms of carbon pricing, are a relatively simple instrument: according to the expertise collected by the World Bank - the EU Emissions Trading System are best suited for industrial actors that have the capacity and skills to engage in the market actively [5, p. 6]; are a promising way to reduce emissions of carbon dioxide and other greenhouse gases while avoiding unnecessary costs $[6, \mathrm{p} .1]$, including in transport and waste, industry and energy [5, p.1], and also to reduce air pollution $[1$, p. $3 ; 2$, p. $2,4,16]$; can be effective for domestic resource mobilization, e.g. to finance green transitions or budget consolidations $[4$, p. $4 ; 2$, p. 2, 25], and to reduce government borrowing [6, p.3]; can help to ensure that aid flows into Paris-compatible projects [2, p.4]. In this context it is important to balance carbon pricing with gradual increase of tax levels during some time [5, p. 2, 10, 16] and also are necessary measures that ensure affordable access to cleaner alternatives [2, p. 2].

In addition to the listed advantages, a carbon tax can help to neutralize the barriers to export growth and, as a result, prevent the reduction of foreign exchange earnings in countries outside the EU if the Governments minimize the risks associated to imposing a carbon border adjustment mechanism according to European Green Deal [7, p. 5] no later than 2023.The EU could exempt from Carbon Border Tax countries with carbon-pricing mechanisms that the EU agrees are compatible with its own and by negotiating new preferential trade agreements or updating existing ones [8, p. 2].

One key element of carbon taxes is the way of how do the governments spend its potentially considerable revenues $[6$, p. 1, 12] and impossibility perceptions of unfairness and inefficiency their use $[1$, p. $13 ; 2$, p. $2-3 ; 5$, p.13].

Carbon taxes revenues in addition of its economically analogous fuel excise taxes can be used to:

- (1) offsetting the new burdens that a carbon tax places on consumers, producers, communities, and the broader economy [2, p. 3; 5, p. 3, 15; 6, p. 1] (for example: cuts in other taxes [1, p. 6], including reducing payroll taxes $[1$, p. $16 ; 4$, p. 4$]$; targeted assistance and compensation: to lowerincome households, including to the indirect cost compensation for higher electricity prices resulting from the carbon tax; for displaced workers and coal-mining regions; to companies [1, p. 17-18; 2, p. 12, 15] suffering from reduced demand carbon-intensive products, etc.); 
- (2) supporting further efforts to reduce greenhouse gas emissions $[4$, p. $4 ; 5$, p. 12,$17 ; 6$, p. 1] (investments toward low-carbon sources [1, p. 1], public infrastructure investment (for example, charging stations for electric vehicles), public spending on technologies of carbon capture and storage, smart grids, batteries to store intermittent renewable power $[1$, p. 20,21$]$.

- (3) funding public priorities unrelated to climate. [5, p. 6; 6, p. 1].

Government should regularly estimate and report the public about effects of carbon tax implementation and regularly inform the way these revenues have been used. Governments, moreover, can use commitment devices, such as explicit plans which based on the best available proves for the revenues to be redistributed $[5$, p. 3, 17]. The Ministers of finance in all countries play the main roles in the policies of implementing the emissions reductions rules in the most efficient, equitable, socially and politically acceptable way [1, p. 22].

For the purpose of goals achievements of the cost-efficient use carbon taxes revenues and budgeting investment to reduce greenhouse gas emissions, - a key role for the Ministry of finance of the EaP may play «Guidelines on State aid for environmental protection and energy 2014-2020 [9] whose validity has been prolonged by the European Commission $(E C)$ until 31 December 2021. The current Guidelines already contain directions, which correspond with the IMF's recommendations $[1$, p. 1, 20, 21] of budget support for low-carbon investments, and would be updated by the EC according to the European Green Deal.

As a result, the above arguments of the benefits and conditions that concern effective use of the carbon tax can be used to make optimal management decisions by the Governments of EaP Countries in the conditions of limited financial resources, global challenges of climate change and the Covid-19 pandemic, new priorities and EU market rules. The systemic multi-purpose effects from the carbon tax presented in these theses, with expediency of bringing certain mechanisms of taxation and budgeting policies of $\mathrm{EaP}$ countries acoding to the international and european standards, - may also be useful for determining the priorities of international technical assistance with a grant component for scientific researches $[3$, p. 126, 135].

\section{References:}

1. Fiscal monitor: How to mitigate climate change/ International Monetary Fund, October 2019. URL: https://www.imf.org/-/media/Files/ 
Publications/fiscal-monitor/2019/October/English/text.ashx

(access date: 01.02.2021)

2. Taxing energy use for sustainable development: Opportunities for energy tax and subsidy reform in selected developing and emerging economies/ OECD, 2021. URL: https://www.oecd.org/tax/tax-policy/taxingenergy-use-for-sustainable-development.pdf (access date: 23.02.2021)

3. Мороз О. Апроксимація механізмів функціонування систем фінансових послуг до міжнародних та європейських стандартів. Вісник Академії праиі, сочіальних відносин. 2020. № 1-2. С. 125-138. URL: https://www.socosvita.kiev.ua/sites/default/files/Visnyk_1-2_2020125-138.pdf (access date: 07.07.2020)

4. Heine, D., Semmler, W., Mazzucato, M., Braga, J.P., Flaherty, M., Gevorkyan, A., Hayde, E., Radpour, S. Policy research working paper № 8991: Financing low-carbon transitions through carbon pricing and green bonds/ World Bank Group, August 2019. URL: http://documents1.worldbank.org/curated/en/808771566321852359/pdf/Fina ncing-Low-Carbon-Transitions-through-Carbon-Pricing-and-GreenBonds.pdf (access date: 25.01.2021)

5. Carattini, S., Carvalho, M. \& Fankhauser, S. Policy report: How to make carbon taxes more acceptable /The Centre for Climate Change Economics and Policy \& The Grantham Research Institute on Climate Change and the Environment, December 2017. URL: https://www.lse.ac.uk/ GranthamInstitute/wp-content/uploads/2017/12/How-to-make-carbon-taxesmore-acceptable.pdf (access date: 18.01.2021)

6. Marron, D.B. \& Morris, A.C. How to use carbon tax revenues/ Tax Policy Center/Urban Institute \& Brookings Institution, February 2016. URL: https://www.brookings.edu/wp-content/uploads/2016/07/howtousecarbontaxrevenuemarronmorris-1.pdf (access date: 20.01.2021)

7. Communication from the Commission to the European Parliament, the European Council, the Council, the European Economic and Social Committee and the Committee of the Regions «The European Green Deal» [COM(2019) 640 final], 11 December 2019. URL: https://eur-lex.europa.eu/legal-content/EN/TXT/?qid=1576150542719 \&uri=COM\%3A2019\%3A640\%3AFIN (access date: 09.01.2021)

8. Aylor, B., Gilbert, M., Lang, N., McAdoo, M., Öberg, J., Pieper, C., Sudmeijer, B. \& Voigt, N. How an EU Carbon Border Tax Could Jolt World Trade / Boston Consulting Group, 2020. URL: https://image-src.bcg.com/ Images/BCG-How-an-EU-Carbon-Border-Tax-Could-Jolt-World-Trade-Jun2020_tcm9-252002.pdf (access date: 11.02.2021) 
9. Communication from the Commission «Guidelines on State aid for environmental protection and energy 2014-2020» (2014/C 200/01). Official Journal of the European Union. 28 March 2014. C. 200. Pp. 1-55. URL: https://eur-lex.europa.eu/legal-content/EN/TXT/PDF/?uri=CELEX: 52014XC0628(01)\&from=EN (access date: 21.02.2021)

DOI https://doi.org/10.30525/978-9934-26-045-2-23

\title{
ОСОБЛИВОСТІ ЗАКОНОДАВЧОГО ЗАБЕЗПЕЧЕННЯ РЕАЛІЗАЦІЇ ДЕРЖАВНО-ПРИВАТНОГО ПАРТНЕРСТВА: ПРОБЛЕМИ ТА ПЕРСПЕКТИВИ
}

\author{
Палажченко К. С. \\ аспірантка кафедри теорії та практики управління \\ Начіонального технічного університету України \\ «Киїський політехнічний інститут імені Ігоря Сікорського» \\ м. Київ, Україна
}

Полеміка щодо питань альтернативних форм фінансування суспільно значущих проектів, протягом останнього десятиліття набирає все більшої актуальності і імперативно пов'язано 3 інноваційними процеси, які відіграють вирішальну роль у контексті розвитку економіки України. Саме тому, важливим завданням виступає дослідження та впровадження передових форм, механізмів та моделей, що мають на меті підвищення ефективності виробництва та надання соціальних та інфраструктурних послуг. Однією 3 альтернатив розвитку визначальних галузей економіки та зменшення фінансового навантаження на бюджет є механізм державно-приватного партнерства (далі - «ДПП»). Позитивна практика поєднання роботи державних і приватних структур може стати каталізатором змін, врахувавши не лише інтереси держави, а й інших учасників ДПП: бізнесових структур та інших стейкколдерів.

Модель співпраці держави та бізнес структур успішно функціонує у багатьох розвинених країнах світу та дає змогу підвищити ефективність використання об'єктів державної власності на основі використання ресурсів приватного сектору.В умовах дефіциту державного бюджету розвиток такої моделі співпраці $\epsilon$ важливим завданням для України. Початок впровадження взаємодії державного та приватного секторів економіки в Україні розпочався із встановленням 